\title{
NCPDP DEA Schedule Terminology
}

National Cancer Institute

\section{Source}

National Cancer Institute. NCPDP DEA Schedule Terminology. NCI Thesaurus. Code C89507.

A terminology subset for the NCPDP that contains concepts within the Drug Enforcement Administration (DEA) Schedule of Controlled Substances. 